\title{
ФОРМУВАННЯ ГРОМАДЯНСЬКОЇ СВІДОМОСТІ УЧНІВСЬКОЇ МОЛОДІ ЗАСОБАМИ ХОРЕОГРАФІЧНОГО МИСТЕЦТВА
}

\author{
Тіщенко О. М. \\ кандидат педагогічних наук, викладач кафедри хореографії, \\ Харківський національний педагогічний університет імені Г. С. Сковороди, \\ м. Харків, Україна
}

Громадянське виховання виявляється в культурологічному вияві, сочіальній інформації, у спонуканні до суспільної діяльності. Воно впливає на становлення духовних потреб і інтересів особистості, етичну і естетичну вихованість, правову свідомість і поведінкову, художні ідеали і смаки людей.

Ключові слова: духовність, громадянськість, громадянське виховання, громадянське виховання засобами хореографії, народний танеиь.

Civic education is expressed in culture, social information and motivation for social activity. Civic education influences the formation of spiritual person's needs and interests, ethical and aesthetic manners, legal consciousness and behaviour, artistic ideals and tastes of people.

Key words: spirituality, citizenship, civic education, civic education by means of choreography, folk dance.

У Національній доктрині розвитку освіти України в XXI столітті зазначено, що виховання особистостей, які, володіють високою моральністю, виявляють національну і релігійну терпимість, поважають традиції і культуру інших народів, є основним завданням освіти в сучасному суспільстві. Вирішення цього завдання можливе лише шляхом внутрішніх змін особистості, переорієнтації людей на духовні цінності.

Ці ідеї можна зустріти ще у роботах педагогів-класиків. Так, у праці «Еміль, або про виховання» Ж.-Ж. Руссо одним із правил виховання визначає таке: «Навчіть нашого вихованця любити всіх людей I навіть тих, хто їх зневажає; зробіть так, щоб він не відносив себе до жодного класу, але щоб він виявлявся в усіх класах; говорив при ньому про рід людський зворушливо, навіть 3 жалістю, але ніколи не відгукуйтесь про нього з презирством». Ж.-Ж. Руссо писав, що потрібно виховувати у дітей повагу до різних людей; а I. Г. Песталоцці висловлював думку про те, що необхідно виховувати всіх дітей як одну сім'ю, не звертаючи уваги на їхню національність [3, с.282]. 
Духовність і громадянськість, на нашу думку, є невід'ємними складовими формування особистості, які тісно пов'язанні між собою, бо виховання любові до своєї землі, історії, мови, культури свого народу - це виховання в дусі національних пріоритетів, національної самосвідомості як органічної частини загальнолюдських цінностей.

Один з основоположників громадянського виховання початку ХХ ст. німецький педагог Г. Кершенштейнер, який аналізував питання громадянського виховання і називав цей процес: «привчання молоді служити громаді». В основу цього процесу він покладав почуття, емоції, мораль [2].

К. Д. Ушинський вважав, що моральну основу громадянина визначають почуття, які формуються через виховання самосвідомості [4].

Виховання - робота творча. Вона не знає універсальних засобів на всі випадки життя, вимагає постійного пошуку, уміння встигати за життям.

Політика — це форма суспільної свідомості, забезпечення корінних інтересів суспільства, соціальних і національних груп в зрізах внутрішнього устрою життя і міжнародних відносин. Громадянське виховання визначається суспільним світоглядом. Воно включає сукупність суспільно значущих поглядів, переконань, ціннісних орієнтацій, соціальних і національних груп, окремої людини.

Громадянська свідомість немислима без розвиненого політичного мислення, здатності глибоко осмислювати політичні події, давати їм оцінку, робити тактичні і стратегічні висновки відносно напрямків культурного й суспільного розвитку.

Громадянське виховання засобами хореографії базується на ціннісно-духовній, національній культурі.

Будучи мистецтвом загальнолюдським, доступним без будь-якого перекладу людям всіх рас і континентів, танок завжди містить у собі певне національне забарвлення. Проводячи аналогію із музикою, треба відмітити, що подібно до того, як музичні інтонації, що народжені з урахуванням реалістичних життєвих інтонацій певної історичної епохи і носять яскраво виражений національний характер, пластичні танцювальні рухи мають в того чи іншого народу неповторний національний характер. Мова пластики є зрозумілою у «натуральному» вигляді, що його створив народ. Хореографія, як вища форма танцювального мистецтва, увібрала у себе риси національної специфіки, але 
ступінь співвідношення у ній національного і загальнолюдського має особливі закономірності.

Народний танок можна $з$ упевненістю називати найпоширенішим видом танцювального мистецтва у світі. Саме він підтверджує відому метафору: «Життя — це танок». Немає жодної народності, якої б нечисленною вона не була, яка не мала б властивої тільки їй рухової культури, що має більше, ніж тільки побутове призначення. Безумовно, оцінка цих рухових культур для самих народів і в історії людства різна. Танцювальне мистецтво деяких країн популярне тільки в межах тих країни, а у інших - завоювало весь світ.

М. В. Гоголь, говорячи про творче використання діячами хореографії танцювального фольклору, писав: «Керуючись тонкою розбірливістю, творець балету зможе брати скільки хоче для визначення характерів, які дають поняття про своїх героїв». Саме через правдиву реалізацію хореографічних образів М. Гоголь закликав хореографів не відриватися від рідного національного грунту, вбирати образи і світовідчуття, мудрість і фантазію, свіжість та глибину. Тут усе залежить від самого хореографа. Народне танцювальне мистецтво є умовою не тільки зростання духовної культури особистості, але й формування іiі естетичного світогляду [1].

Риси українського народного танцю у контексті порівняльного аналізу з розвитком аналогічних танцювальних форм у культурах західних країн свідчать про його специфічність не тільки у світоглядних вимірах народної культури, але й професійної. Ця специфічність яскраво простежуються на прикладі козацького танцю доби бароко, який, не втрачаючи зв'язків з народними традиціями, акумулює в собі ті зміни, які відбуваються у національному житті українського етносу, виступає нині основою для організації дитячих та молодіжних об'єднань з метою національного, громадянського виховання.

Громадянська спадкоємність простежується на рівні історичнопізнавальної культури та пластики танцювальних жестів, з яких вони складаються, що дає можливість зробити припущення про більш тривалий час формування лексико-інтонаційних ознак мови «Гопака», порівняно із загально визначеним строком, що обмежується добою козаччини.

Ця спадкоємність вказує і на те, що феномен народної хореографії не можна розглядати тільки у контексті фольклорних традицій. Закла- 
дені в їі основу історико-пізнавальні та пластичні коди дають підстави вважати, що вона у багатьох випадках виступає плодом співтворчості «самодіяльного», «фольклорного» і професійного мистецтв.

Художнє бачення світу, творча культура, здібність цінувати красу, неповторність й виразність персонажного образу становлять основу обрядово-української хореографії.

Хореографічне виховання має нині велике значення в усебічному розвитку дитини. Засобами обрядово-танцювального мистецтва можна прищепити в дитини любов до прекрасного, культурного спадку нації та його примноження. Саме таке завдання стоїть перед керівниками хореографічних гуртків у сучасній школі, оскільки процес соціалізації має починатися в ранньому віці.

\section{Список використаних джерел:}

1. Гоголь Н. В. Полное собрание сочинений. Москва, 1987.

2. Кершенштейнер Г. Избранные сочинения. Москва : Тихомиров, 1915.

3. Руссо Ж. Ж. Эмиль, или о воспитании. Педагогическое наследие / Сост. В. М. Кларин, А. Н. Джуринский. Москва, 1987. С.199-297.

4. Ушинський К. Д. Вибрані педагогічні твори: в 2 т. Київ : Радянська школа, 1983. Т. 1. 